\title{
Correction to: The gastrointestinal nematodes of Paramelomys lorentzii and Mammelomys spp. (Rodentia: Muridae) with descriptions of a new genus and three new species (Heligmonellidae) from Papua New Guinea and Indonesia
}

\author{
Lesley R. Smales ${ }^{1}$
}

Published online: 8 December 2021

(c) The Author(s) under exclusive licence to Witold Stefański Institute of Parasitology, Polish Academy of Sciences 2021

\section{Correction to: Acta Parasitologica, 2017, 62(4), 762-771 https://doi.org/10.1515/ap-2017-0091}

Since the publication of the paper 'the gastrointestinal nematodes of Paramelomys lorentzii and Mammelomys spp. (Rodentia:Muridae) with descriptions of a new genus and three new species (Heligmonellidae) from Papua New Guinea and Indonesia' Smales LR (2017) Acta Parasitol 62(4):762-771 it has been drawn to my attention that the identification of some of the host individuals has been revised.

Accordingly, the following corrections should be noted.

In the materials and methods section the individual of Paramelomys lorentzii (Australian Museum Registration M13654) collected from Telefomin, PNG is now identified as Mammelomys lanosus and the two individuals of Paramelomys lorentzii (AM M32439, 32,089) collected from Aru Island are now identified as Paramelomys naso.

Consequently, in the taxonomic descriptions of the heligmonellids, the type host of Hughjonestrongylus woolleyae is Paramelomys naso and the other host $P$. lorentzii and the other hosts for Parvinema bafunminensis include the individual of Mammelomys lanosus from Telefomin.

The original article can be found online at https://doi.org/10.1515/ ap-2017-0091.

Lesley R. Smales

1.warner@cqu.edu.au

1 Parasitology Section, South Australian Museum, North

Terrace, Adelaide, SA 5000, Australia
Publisher's Note Springer Nature remains neutral with regard to jurisdictional claims in published maps and institutional affiliations. 